\title{
RELATION OF ACUTE POTASSIUM DEPLETION TO RENAL AMMONIUM METABOLISM IN PATIENTS WITH CIRRHOSIS *
}

\author{
By JUAN M. BAERTL, $\dagger$ SALVATORE M. SANCETTA, AND GEORGE J. GABUZDA
}

(From the Department of Medicine, Western Reserve University School of Medicine, and Cleveland Metropolitan General Hospital, Cleveland, Ohio)

(Submitted for publication August 6, 1962 ; accepted January 24, 1963)

Neurologic findings characteristic of the impending hepatic coma syndrome occur in some cirrhotic patients treated with diuretic agents that may induce potassium losses (1-5). Even when diuretic agents are not employed, hypokalemia may be associated with this syndrome (6-8). Patients demonstrating these signs often improve after treatment with potassium salts. This result of therapy might indicate that potassium deficiency per se is a pathogenetic factor in the impending hepatic coma syndrome (9). Because of the extensive evidence relating abnormalities in nitrogen metabolism to hepatic coma (10), however, it seemed possible that some derangement of nitrogen metabolism might be associated with potassium deficiency.

This hypothesis, relating potassium deficiency indirectly to the hepatic coma syndrome by an influence this cation has on ammonium metabolism, provided the rationale for undertaking this investigation. The relation of potassium to ámmonium metabolism was studied in patients with cirrhosis of the liver and ascites rendered acutely potassium deficient by a diuretic regimen. The results of these studies demonstrate that metabolism of ammonium by the kidney is altered in potassium-deficient patients and that significant quantities of ammonium may be delivered to the cir-

* A preliminary report of this investigation was included in the proceedings of the American Association for Study of Liver Disease, Chicago, 1959 (Gastroenterology $1960,38,803)$. This investigation was supported primarily by the Research and Development Division, Office of the Surgeon General. Department of the Army, under contract DA-49-007-MD-749, and in part by U. S. Public Health Service research grant $\mathrm{H}-4302$ and a grant from the Northern Ohio Chapter of the National Kidney Disease Foundation.

$\dagger$ Present address: British American Hospital, Lima, Peru.

$\ddagger$ Address requests for reprints to Dr. George J. Gabuzda, Cleveland Metropolitan General Hospital, Cleveland, Ohio. culating blood from this source. The findings are interpreted in relation to a role of potassium deficiency in the pathogenesis of the hepatic coma syndrome and to the influence of this cation in the regulation of ammonium metabolism by the kidney.

\section{MATERIALS AND METHODS}

Ten patients with cirrhosis of the liver, ascites, and, in some cases, edema were studied in the metabolic ward of the Cleveland Metropolitan General Hospital. Each, except R.C. and A.K., had a history of excessive intake of alcoholic beverages associated with inadequate food intake. All patients had obvious clinical and laboratory evidence for the presence of advanced hepatic cirrhosis. Examination of liver tissue obtained by needle biopsy or at necropsy warranted a diagnosis of Laennec's cirrhosis in R.H., F.F., W.W., and G.S., and of postnecrotic cirrhosis in A.K. and R.C. A.K. and W.W. had additional clinical diagnoses of compensated, arteriosclerotic heart disease and chronic renal disease. W.W. had intermittent 1 to $2+$ proteinuria, and examination of kidneys at autopsy revealed a healed focal pyelonephritis. All patients were mentally clear and free of neurologic signs of impending hepatic coma at the time the studies were initiated, although E.H., W.D., and E.N. had demonstrated such signs earlier during their hospitalizations.

Patients were ambulatory within the metabolic ward. Food and fluid intakes were constant during and for 6 days before each patient study. Fluid intakes ranged from 1,000 to $2,500 \mathrm{ml}$ daily. The constant diets provided 1,800 to 2,500 calories, 46 to $75 \mathrm{~g}$ protein daily, and contained 7 to $11 \mathrm{mEq}$ sodium and 52 to $90 \mathrm{mEq}$ potassium. The compositions of the diets used were calculated from standard reference materials (11-15).

Each study consisted of : a) a 1- to 3-day control period: b) 4 days of oral calcium chloride administration: c) the intramuscular administration of a mercurial diuretic (Thiomerin, ${ }^{1} 2 \mathrm{ml}$ ) on the morning of day 4 of calcium chloride administration; in 11 of the 22 studies, followed after 1 hour by the slow (within 10 to $15 \mathrm{~min}$ utes) intravenous administration of $0.5 \mathrm{~g}$ of aminophylline; and $d$ ) a recovery period.

Patients were weighed daily under constant conditions before breakfast. Urine samples were kept at $4^{\circ} \mathrm{C}$ with $10 \mathrm{ml}$ of $10: 1$ mixture of glacial acetic acid and

1 Mercaptomerin sodium. 
toluol as preservative until completion of each daily collection. Total volumes were then measured and suitable samples stored at $-20^{\circ} \mathrm{C}$ for subsequent analysis. For R.C. and E.N., urine specimens were collected under oil and thymol as preservative and stored at $4^{\circ} \mathrm{C}$ until completion of each day's collection when $\mathrm{pH}$ was determined. Then total volumes were measured, glacial acetic acid was added as preservative, and samples were stored at $-20^{\circ} \mathrm{C}$.

Samples of arterial blood were obtained from fasted patients as follows: $a$ ) during the control period and on day 1 of calcium chloride, but prior to its administration; $b)$ on the day the diuretic was given; $c$ ) daily in the early recovery period; and $d$ ) then at suitable intervals. Blood samples were obtained in separate syringes for determinations of ammonium nitrogen, electrolytes, and $\mathrm{pH}$. Blood for ammonium nitrogen analyses was transferred to Conway dishes immediately after shedding. Blood for $\mathrm{pH}$ was obtained anaerobically in heparinized syringes and analyzed immediately. Blood for electrolyte determinations was allowed to clot for 45 minutes after shedding and then centrifuged. The sera were separated promptly and stored at $-20^{\circ} \mathrm{C}$ until analyzed. Electrocardiographic tracings were recorded before and a day after the induction of a diuresis.

In addition to arterial and peripheral venous blood samples, blood was obtained from the right renal vein and hepatic vein in four patients and from the jugular bulb in three patients by application of cardiac catheterization techniques. Each of these patients received $64 \mathrm{mg}$ phenobarbital orally at bedtime the night before and $50 \mathrm{mg}$ sodium pentobarbital orally at 8:00 a.m. the morning of the catheterization procedure. At 8:30 a.m. the patient was taken to the cardiovascular laboratories. A solution of $5 \%$ glucose in water, containing $50 \mathrm{mg}$ heparin per L, was run slowly through the catheter. About 500 $\mathrm{ml}$ of this solution was used for each catheterization. F.F. received saline instead of glucose solution for his first catheterization. Placing of the catheter in the right renal vein was determined by direct fluoroscopic visualization and by the "arterialized" appearance of the venous blood. The differences in oxygen content between peripheral artery and renal vein were determined, and in all instances were less than 2.0 vol per $100 \mathrm{ml}$.

F.F. was catheterized after 3 days of calcium chloride administration and again about 72 hours after the induction of the mercurial diuresis. W.D. and E.N. were catheterized after two days of calcium chloride loading and again 48 hours after administration of the diuretic. The one catheterization for R.C. was done about 48 hours after the mercurial diuretic was given. Arterial blood samples were obtained for ammonium nitrogen determinations simultaneously with each sample of renal venous blood. At the time of collection of renal venous blood for ammonium nitrogen determination, samples for analysis of potassium content and $\mathrm{pH}$ were obtained, and within a few minutes, arterial blood was also obtained for these determinations. During the one catheterization procedure in R.C., and the second procedures in W.D. and E.N., potassium gluconate $(0.25 \mathrm{M}$ solution, $\mathrm{pH} 7.00)$ was infused through the exploring catheter as recorded with each patient's data (Tables IV and V). Immediately after the infusion was completed, blood samples were again obtained from artery and renal vein. Peripheral venous blood was obtained simultaneously with renal venous blood for determination of ammonium nitrogen concentration. E.N. was given 60 mmoles of glucose ( $200 \mathrm{ml}$ of $5 \%$ glucose in distilled water) in 40 minutes during his first catheterization as a control study.

Fractional urine samples were collected through indwelling catheters before and during potassium gluconate administration in E.N. and R.C. and also before and during the glucose infusion in E.N. Continuous electrocardiographic tracings were made during the infusions of potassium. Potassium was given until the $T$ waves, which had become abnormal after the diuresis, clearly became normal.

After the catheterization procedure was completed, the patient was returned to the metabolic unit, and the constant regimen was resumed with minimal disruption, except for the unavoidable alteration in times of feeding.

Each 24-hour urine sample was analyzed for total nitrogen content by the Kjeldahl method (16). Serum urea nitrogen was determined by the method of Owings and Mandel (17). Serum and urine sodium and potassium concentrations were determined by flame photometry (18), and chloride concentrations by Sendroy's technique (19) in all patients except R.C. and E.N. For these two patients, urine and sera samples were analyzed for chloride content by the amperometric method devised by Cotlove, Trantham, and Bowman (20).

Blood and urine ammonium nitrogen concentrations were measured by a modification of the Conway microdiffusion technique (21-23). Urine $\mathrm{pH}$ and $\mathrm{pH}$ of blood were determined anaerobically at $37^{\circ} \mathrm{C}$ either with a Beckman model $\mathrm{G}$ or with a Cambridge $\mathrm{pH}$ meter (research model).

\section{RESULTS}

Response to diuretic regimen. Data demonstrating the effects of oral calcium chloride administration and the mercurial diuretic on complete blood and urine electrolyte patterns are not presented, since the metabolic alterations resulting from these agents are well-known. The calcium chloride produced a metabolic acidosis with increases in serum chloride concentration and decreases in blood $\mathrm{pH}$. The renal responses of these patients to the induced acidosis. in general, compared to those noted for normal individuals in regard to ammonium excretion (24). Their excretions of sodium in response to acid loading compared to those that occur in normal individuals depleted of sodium or fed sodium-restricted diets $(25,26)$. 
TABLE I

Effect of diuretic regimen on potassium and

\begin{tabular}{|c|c|c|c|c|c|c|c|c|c|c|c|c|c|}
\hline & & & & & & & & & & \multicolumn{4}{|c|}{ Cirrhosis } \\
\hline \multicolumn{2}{|c|}{$\begin{array}{l}\text { Patient, age, sex: } \\
\text { No. of experiments :* }\end{array}$} & \multicolumn{4}{|c|}{ J.H., $448, M$} & \multicolumn{4}{|c|}{ F.F., ${ }_{2}^{43}, M$} & \multicolumn{4}{|c|}{ W.D., ${ }_{2}^{41,} \mathrm{M}$} \\
\hline \multirow[b]{2}{*}{ Day } & \multirow[b]{2}{*}{ Period } & \multicolumn{2}{|c|}{ Blood } & \multicolumn{2}{|c|}{ Urine } & \multicolumn{2}{|c|}{ Blood } & \multicolumn{2}{|c|}{ Urine } & \multicolumn{2}{|c|}{ Blood } & \multicolumn{2}{|c|}{ Urine } \\
\hline & & $\mathrm{K}$ & $\overrightarrow{\mathrm{NH}_{4}-\mathrm{N}}$ & $\mathrm{K}$ & $\overline{\mathrm{NH}_{4}}$ & K & $\overline{\mathrm{NH}_{4}-\mathrm{N}}$ & $\mathrm{K}$ & $\mathrm{NH}_{4}$ & $\mathrm{~K}$ & $\overline{\mathrm{NH}_{4}-\mathrm{N}}$ & $\mathrm{K}$ & $\mathrm{NH}_{4}$ \\
\hline & & $m E q / L$ & $\stackrel{\mu g /}{100 \mathrm{ml}}$ & $\underset{d a y}{m E q /}$ & $\underset{d a y}{m E q /}$ & $m E q / L$ & $\stackrel{\mu g /}{100 \mathrm{ml}}$ & $\underset{d a y}{m E q /}$ & $\underset{d a y}{m E q /}$ & $m E q / L$ & $100 \mathrm{ml}$ & $\underset{d a y}{m E q /}$ & $\underset{d a y}{m E q /}$ \\
\hline 1 & Control & & & 49 & 42 & & & 43 & 31 & & & 31 & 27 \\
\hline 2 & Control & 3.6 & 70 & 42 & 43 & & & 46 & 34 & 4.6 & 42 & 32 & 21 \\
\hline 3 & Control & & & 43 & 41 & & & 37 & 28 & & & 39 & 28 \\
\hline 4 & $\mathrm{CaCl}_{2}$, oral $\dagger$ & 3.9 & 84 & 41 & 54 & 4.7 & 56 & 51 & 45 & 3.9 & 46 & 22 & 35 \\
\hline 5 & $\mathrm{CaCl}_{2}$, oralt & & & 60 & 92 & & & 80 & 92 & & & 28 & 59 \\
\hline 6 & $\mathrm{CaCl}_{2}$, oral $\dagger$ & & & 67 & 112 & & & 61 & 108 & 4.4 & 44 & 47 & 88 \\
\hline 7 & $\begin{array}{c}\mathrm{CaCl}_{2} \text {, oral† } \\
\text { Mercurial } \\
\text { diuretic, im }\end{array}$ & 3.8 & 89 & 208 & 167 & 4.4 & 43 & 185 & 143 & 4.8 & 34 & 271 & 150 \\
\hline 8 & Control & 2.4 & 128 & 17 & 92 & 3.7 & 64 & 24 & 77 & 2.7 & 56 & 25 & 80 \\
\hline 9 & Control & 3.2 & 143 & 14 & 54 & 3.7 & 104 & 4 & 49 & 2.8 & 101 & 19 & 62 \\
\hline 10 & Control & 3.7 & 100 & 14 & 50 & 3.8 & 70 & 3 & 51 & 3.4 & 77 & 18 & 63 \\
\hline 11 & Control & 3.8 & 94 & 29 & 40 & 4.0 & 72 & 3 & 45 & & & 16 & 43 \\
\hline 12 & Control & & & 41 & 34 & & & 5 & 38 & 4.2 & 63 & 23 & 43 \\
\hline 13 & Control & & & 41 & 35 & 4.3 & 45 & 10 & 38 & & $\cdot$ & 23 & 37 \\
\hline 14 & Control & 3.9 & 90 & 68 & 31 & & & 37 & 30 & & & 19 & 28 \\
\hline 15 & Control & & & 79 & 30 & 4.6 & 53 & 46 & 25 & & & 27 & 31 \\
\hline
\end{tabular}

* The figures presented represent mean values for the number of experiments indicated for each patient.

+ Each patient, except A.K., was given $200 \mathrm{mEq}$ of chloride on each of these days as a solution of calcium chloride containing 1 or 2 mEq per

All patients exhibited a diuretic response to the mercurial diuretic given intramuscularly on day 4 of calcium chloride administration. Increases in urine volume ranged from 1.4 to $6.1 \mathrm{~L}$ and averaged about $3.5 \mathrm{~L}$. The diureses were reflected by decreases in body weight ranging from 1.6 to 6.5 $\mathrm{kg}$, averaging $3.7 \mathrm{~kg}$ for the group. On the day of the diuresis, marked increases in the urinary excretion of chloride, sodium, and potassium and a continuing increase in ammonium excretion occurred. During the subsequent days of recovery, losses of body weight were sustained, and urine volumes approximated control values.

After a diuresis, especially if in excess of $3 \mathrm{~L}$ of urine, patients frequently complained of anorexia, muscular weakness, and fatigability. Decreased audible peristalsis with gaseous abdominal distention sometimes occurred. Constipation was a relatively frequent complaint. E.H. also showed diminution in peripheral tendon reflexes after each diuresis, and exhibited signs and symptoms of impending hepatic coma including changes in mental status, flapping tremor, and electroencephalographic pattern.

Electrocardiographic tracings were made on the day of the diuresis and on the following day. Sig- nificant depression in the ST segment and flattening of the $T$ waves often occurred within 24 hours. In some patients these electrocardiographic changes were apparent within 4 to 6 hours after the administration of the diuretic agent. These alterations, interpreted as indicative of changes in potassium metabolism, reverted to normal as serum potassium levels increased during recovery periods, owing either to the potassium contained in the control diet or to supplementation with potassium salts.

Ammonium and potassium metabolism. Reproducibility of arterial blood ammonium nitrogen and serum potassium levels from day to day in fasted alert patients with cirrhosis was determined by evaluating statistically 17 pairs of observations obtained in 9 of the subjects for each of these constituents. The following results were obtained:

$\begin{array}{lcc} & \mathrm{NH}_{4-\mathrm{N}} & \mathrm{K} \\ \mu \mathrm{g} / \mathrm{N} 00 \mathrm{ml} & m E q / L \\ \text { Range of reproducibility } & -8 \text { to }+18 & -0.4 \text { to }+0.3 \\ \text { Mean } & +2.4 & +0.03 \\ \text { SE of mean } & \pm 2.0 & \pm 0.06 \\ \text { SD of mean } & \pm 8.2 & \pm 0.22\end{array}$

Although excretion of ammonium into the urine increased progressively after calcium chloride administration, arterial blood ammonium concentra- 
ammonium metabolism in seven patients

\begin{tabular}{|c|c|c|c|c|c|c|c|c|c|c|c|c|c|c|c|}
\hline & & & & & & & & \multicolumn{8}{|c|}{ Cirrhosis and renal disease } \\
\hline \multicolumn{4}{|c|}{ R.H., $38, F$} & \multicolumn{4}{|c|}{ G.S., $58, M$} & \multicolumn{4}{|c|}{ W.W., $63, M$} & \multicolumn{4}{|c|}{ A.K., $77, F$} \\
\hline \multicolumn{2}{|c|}{ Blood } & \multicolumn{2}{|c|}{ Urine } & \multicolumn{2}{|c|}{ Blood } & \multicolumn{2}{|c|}{ ' Urine } & \multicolumn{2}{|c|}{ Blood } & \multicolumn{2}{|c|}{ Urine } & \multicolumn{2}{|c|}{ Blood } & \multicolumn{2}{|c|}{ Urine } \\
\hline $\mathrm{K}$ & $\mathrm{NH}_{4}-\mathrm{N}$ & $\mathrm{K}$ & $\mathrm{NH}_{4}$ & $\mathbf{K}$ & $\mathrm{NH}_{4}-\mathrm{N}$ & $\mathbf{K}$ & $\mathrm{NH}_{4}$ & K I & $\mathrm{NH}_{4}-\mathrm{N}$ & $\mathbf{K}$ & $\mathrm{NH}_{4}$ & K I & $\mathrm{NH}_{4}-\mathrm{N}$ & $\mathbf{K}$ & $\mathrm{NH}_{4}$ \\
\hline \multirow[t]{2}{*}{$m E q / L$} & $100 \mathrm{ml}$ & $\underset{\text { day }}{m E q /}$ & $\underset{\text { day }}{m E q /}$ & $m E q / L$ & $\stackrel{\mu g /}{100 \mathrm{ml}}$ & $\underset{d a y}{m E q /}$ & $\underset{d a y}{m E q /}$ & $m E q / L$ & 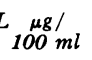 & $\underset{d a y}{m E q /}$ & $\underset{d a y}{m E q /}$ & $m E q / L$ & $100 \mathrm{ml}$ & $\underset{d a y}{m E q /}$ & $\underset{d a y}{m E q /}$ \\
\hline & & & & & & 31 & 37 & 6.4 & 49 & 39 & 24 & & & 41 & 23 \\
\hline \multirow[t]{2}{*}{3.8} & 66 & 25 & 63 & 4.4 & 76 & 25 & 37 & & & 31 & 28 & 4.5 & 59 & 49 & 25 \\
\hline & & 23 & 51 & & & 37 & 36 & & & 39 & 26 & & & 37 & 23 \\
\hline \multirow[t]{3}{*}{3.9} & 72 & 27 & 57 & 4.4 & 81 & 29 & 39 & 5.4 & 49 & 39 & 29 & & & 43 & 25 \\
\hline & & 49 & 98 & & & 37 & 53 & & & 47 & 32 & & & 51 & 31 \\
\hline & & 50 & 119 & & & 65 & 100 & & & 50 & 45 & & & 54 & 42 \\
\hline 4.1 & 56 & 115 & 128 & 4.3 & 77 & 165 & 123 & 5.8 & 54 & 176 & 81 & 4.0 & 49 & 93 & 65 \\
\hline 3.1 & 75 & 12 & 87 & 3.6 & 109 & 12 & 91 & 3.9 & 51 & 72 & 72 & 3.3 & 81 & 30 & 67 \\
\hline \multirow[t]{2}{*}{3.4} & 103 & 9 & 63 & 3.8 & 111 & 7 & 93 & 4.0 & 59 & 17 & 59 & 3.4 & 88 & 17 & 57 \\
\hline & & 18 & 53 & 4.0 & 115 & 8 & 51 & & & 16 & 57 & 3.3 & 83 & 17 & 44 \\
\hline \multirow[t]{5}{*}{4.3} & 79 & 23 & 41 & & & 10 & 51 & 5.0 & 64 & 10 & 52 & 4.0 & 68 & 16 & 44 \\
\hline & & 39 & 30 & & & 30 & 48 & & & 20 & 52 & & & 21 & 40 \\
\hline & & 58 & 36 & & & 37 & 33 & & & 30 & 45 & & & 31 & 37 \\
\hline & & 52 & 39 & & & 34 & 24 & 6.3 & 52 & 23 & 47 & 4.5 & 54 & 37 & 32 \\
\hline & & 48 & 32 & 4.6 & 65 & 41 & 29 & 5.8 & 63 & 28 & 41 & & & 34 & 28 \\
\hline
\end{tabular}

$\mathrm{ml}$ in four divided doses consumed toward the end of each meal. A.K. was given $100 \mathrm{mEq}$ of chloride daily.

tions were unchanged by the acidosis (Tables I and II).

Twenty-four hours after the administration of the mercurial diuretic, significant decreases in serum potassium levels and increases in blood ammonium levels were apparent (Tables I and II). For this day a consistent and significant increment in blood ammonium nitrogen level and decrement in serum potassium concentration occurred in each patient. On day 2 after the diuresis, decreased serum potassium levels were still evident and blood ammonium nitrogen levels were further increased, the latter in most instances reaching maximal elevations on this day. These increments of blood ammonium nitrogen concentrations were highly significant (Table II).

On the day after the diuresis, urinary excretions of ammonium continued above control values; the excretions of potassium promptly decreased below control levels in most patients. Subsequently the urinary excretion of potassium continued at or below control values and then gradually increased. Urine ammonium excretion remained somewhat elevated for several days, gradually returning to control values. Within 6 days serum potassium levels returned to normal and arterial blood am- monium nitrogen concentrations decreased gradually (Table I).

Cirrhosis of liver and chronic renal disease. Metabolic data obtained in two patients with cirrhosis of the liver and ascites, W.W. and A.K., who also had chronic renal disease with persisting azotemia, are included in Table I. These data differ in certain respects from those obtained for the other patients. W.W. demonstrated a decreased urinary ammonium excretion in response

TABLE II

Changes in blood ammonium nitrogen and potassium concentrations compared to control levels*

\begin{tabular}{|c|c|c|c|}
\hline & \multirow{2}{*}{$\begin{array}{l}\text { After } 3 \text { days } \\
\mathrm{CaCl}_{2} \text {, oral }\end{array}$} & \multicolumn{2}{|c|}{ After mercurial diuretic, im } \\
\hline & & Day 1 & Day 2 \\
\hline \multicolumn{4}{|c|}{$\mathrm{NH}_{4}-\mathrm{N} \mu g / 100 \mathrm{ml}$} \\
\hline $\begin{array}{l}\text { Ranget } \\
\text { Mean } \pm \mathrm{SD} \\
\mathrm{p}\end{array}$ & $\begin{array}{l}-20 \text { to }+19 \\
-4 \pm 13 \\
>0.1\end{array}$ & $\begin{array}{l}+9 \text { to }+58 \\
+26 \pm 18 \\
>0.02,<0.05\end{array}$ & $\begin{array}{l}+35 \text { to }+92 \\
+58 \pm 22 \\
<0.001\end{array}$ \\
\hline \multicolumn{4}{|l|}{$\mathrm{K}, m E q / L$} \\
\hline $\begin{array}{l}\text { Ranget } \\
\text { Mean } \pm S D \\
p\end{array}$ & $\begin{array}{l}-0.3 \text { to }+0.6 \\
+0.1 \pm 0.3 \\
>0.1\end{array}$ & $\begin{array}{l}-0.8 \text { to }-1.6 \\
-1.2 \pm 0.4 \\
<0.001\end{array}$ & $\begin{array}{l}-0.6 \text { to }-1.5 \\
-0.9 \pm 0.4 \\
>0.001,<0.01\end{array}$ \\
\hline
\end{tabular}

* These comparisons are derived from the data for the five patient with cirrhosis without renal disease presented in Table $I$ and the mean values from the two experiments for E. H., Table III.

+ Increments, + , or decrements, - , as compared to mean control 
to calcium chloride administration, and both patients showed a persistence of the increased urinary ammonium excretion produced by this agent. A.K. also had increases in blood urea nitrogen concentrations that were not related to decreases in output of urine and small increases in the excretion of nitrogen in the urine following the diuresis. W.W. was the only patient who did not dem-. onstrate significant increases in arterial blood ammonium concentration following the administration of the mercurial diuretic, although potassium losses were consistently induced during each of four experiments. Otherwise these two patients responded similarly to the patients with cirrhosis of the liver without renal disease.

Effect of oral supplementation with potassium gluconate. Because of the reciprocal relationship noted between blood ammonium and potassium levels, a study was designed to determine the effect of oral potassium supplementation on the alterations in blood and urine electrolytes described above. Patient E.H. was selected for this study because he had on several previous occasions demonstrated neurologic signs of impending hepatic coma after the administration of diuretic agents. The basic plan of the two consecutive studies was comparable to that employed for the other patients (Table III).
After each of two diuretic episodes, large amounts of water and electrolytes were excreted, and significant hypokalemia accompanied by increasing arterial blood ammonium concentrations occurred. This patient demonstrated confusion, disorientation, and a flapping tremor following each of these diuretic episodes. On the first occasion, these untoward clinical symptoms of impending hepatic coma were clearly evident on day 2 after the diuresis, increased in severity on day 3 , and then gradually subsided over the next 4 days. On the second occasion, the clinical and metabolic patterns were comparable to those noted during the first experiment; distinct untoward clinical symptoms were again evident on day 2 after the diuresis. The administration of 270 $\mathrm{mEq}$ of potassium as the gluconate daily for 3 days beginning on postdiuretic day 2 was followed by a prompt return of biochemical alterations and of electrocardiographic pattern to normal. Clinical symptoms did not progress after potassium was given, and neurologic status returned to normal in 3 days. Potassium administration corrected the potassium deficit induced by the diuretic regimen. Resulting increases in serum potassium levels were accompanied by decreases in arterial blood ammonium levels. The rate of decrease of blood ammonium level was greater when

TABLE III

Effect of oral potassium gluconate in a patient (E.H., M, age 57) with cirrhosis rendered potassium-deficient by diuresis

\begin{tabular}{|c|c|c|c|c|c|c|c|c|c|c|c|}
\hline \multirow[b]{3}{*}{ Day } & \multirow[b]{3}{*}{ Period } & \multicolumn{5}{|c|}{ Experiment 1} & \multicolumn{5}{|c|}{ Experiment 2} \\
\hline & & \multicolumn{2}{|c|}{ Blood } & \multicolumn{2}{|c|}{ Urine } & \multirow[b]{2}{*}{$\mathrm{IHC}+$} & \multicolumn{2}{|c|}{ Blood } & \multicolumn{2}{|c|}{ Urine } & \multirow[b]{2}{*}{$\mathrm{IHC} \dagger$} \\
\hline & & $\mathbf{K}$ & $\mathrm{NH}_{4}-\mathrm{N}$ & $\mathbf{K}$ & $\mathrm{NH}_{4}$ & & $\mathbf{K}$ & $\mathrm{NH}_{4}-\mathrm{N}$ & $\mathbf{K}$ & $\mathrm{NH}_{4}$ & \\
\hline \multirow{7}{*}{$\begin{array}{l}1 \\
2 \\
3 \\
4 \\
5 \\
6\end{array}$} & & $m E q / L$ & $100 \mathrm{ml}$ & $m E q$ & $m E q$ & & $m E q / L$ & $100 \mathrm{ml}$ & $m E q$ & $m E q$ & \\
\hline & Control & 4.2 & 136 & 17 & 47 & 0 & 4.5 & 137 & 24 & 57 & 0 \\
\hline & Control & & & 17 & 57 & 0 & & & 29 & 59 & 0 \\
\hline & $\mathrm{CaCl}_{2}$, oral, $216 m E q$ & 4.5 & & 49 & 58 & 0 & & & 46 & 67 & 0 \\
\hline & $\mathrm{CaCl}_{2}$, oral, $216 m E q$ & 4.6 & & 47 & 76 & 0 & & & 84 & 88 & 0 \\
\hline & $\mathrm{CaCl}_{2}$, oral, $216 m \mathrm{E}_{q}$ & 4.3 & & 45 & 88 & 0 & & & 90 & 93 & 0 \\
\hline & $\begin{array}{l}\mathrm{CaCl}_{2} \text {, oral, } 210 \mathrm{mEq} \\
\text { Thiomerin, im, } 2 \mathrm{ml} \\
\text { Aminophyllin, iv, } 0.5 \mathrm{~g}\end{array}$ & 4.5 & 128 & 265 & 152 & 0 & 4.4 & 106 & 269 & 139 & 0 \\
\hline 7 & Control & 2.9 & & 34 & 82 & 0 & 2.6 & 164 & 27 & 83 & 0 \\
\hline 8 & Control* & 3.1 & 224 & 2 & 69 & $2+$ & 3.1 & 233 & 7 & 52 & $2+$ \\
\hline 9 & Control* & 3.0 & & 2 & 65 & $4+$ & 4.5 & 133 & 43 & 23 & $1+$ \\
\hline 10 & Control* & 3.0 & 182 & 1 & 61 & $3+$ & 5.5 & 117 & 162 & 9 & \pm \\
\hline 11 & Control & 3.1 & 174 & 2 & 57 & $2+$ & & & 73 & 16 & 0 \\
\hline 12 & Control & 3.0 & 152 & 3 & 55 & $1+$ & & & 46 & 30 & 0 \\
\hline 13 & Control & & & & & \pm & 4.6 & 123 & 39 & 36 & 0 \\
\hline
\end{tabular}

* Potassium, $270 \mathrm{mEq}$ as potassium gluconate, was given in divided doses orally on each of these days during experiment 2 .

† IHC = signs and symptoms of impending hepatic coma. Flapping tremor, change in mental state, and electroencephalographic pattern were used to grade severity on a 0 to $4+$ scale. 
TABLE IV

Data for two patients studied by venous catheterization techniques*

\begin{tabular}{|c|c|c|c|c|c|}
\hline & \multicolumn{2}{|c|}{ F.F. $t$} & \multicolumn{3}{|c|}{ W.D. $\ddagger$} \\
\hline & \multirow[t]{2}{*}{ Day 7} & \multirow[t]{2}{*}{ Day 10} & \multirow[t]{2}{*}{ Day 6} & \multicolumn{2}{|c|}{ Day 9} \\
\hline & & & & & $\overline{\text { K gluconate } \delta}$ \\
\hline \multicolumn{6}{|l|}{$\mathrm{NH}_{4}-\mathrm{N} \mu \mathrm{g} / 100 \mathrm{ml}$} \\
\hline $\begin{array}{l}\text { Artery, initial } \\
\text { Renal vein } \\
\text { Antecubital vein } \\
\text { Hepatic vein } \\
\text { Jugular bulb } \\
\text { Artery, final }\end{array}$ & $\begin{array}{l}35 \\
54 \\
16 \\
31 \\
\\
32\end{array}$ & $\begin{array}{r}53 \\
106 \\
27 \\
40 \\
52\end{array}$ & $\begin{array}{l}44 \\
62 \\
16 \\
36 \\
37 \\
42\end{array}$ & $\begin{array}{r}86 \\
256 \\
39 \\
92 \\
71\end{array}$ & $\begin{array}{l}62 \\
99\end{array}$ \\
\hline \multicolumn{6}{|l|}{$\mathrm{pH}$} \\
\hline Artery & 7.37 & 7.44 & 7.44 & 7.50 & 7.52 \\
\hline \multicolumn{6}{|l|}{$\mathrm{K}, m E q / L$} \\
\hline Artery & 4.5 & 3.7 & 5.0 & 2.5 & 3.7 \\
\hline
\end{tabular}

* These data were obtained during the second of two experiments done with each of these patients. Illustrative day to day data are shown in Table I.

+ Day $7=$ after 3 days oral $\mathrm{CaCl}_{2} ;$ day $10=3$ days after diuresis.

$\ddagger$ Day $6=$ after 2 days oral $\mathrm{CaCl}_{2}$; day $9=2$ days after diuresis.

$\S$ The potassium gluconate was given during a 30 -minute period.

TABLE V

Effects of potassium gluconate infusions in two potassium-depleted patients*

\begin{tabular}{|c|c|c|c|c|c|c|}
\hline \multirow{2}{*}{$\begin{array}{l}\text { Patient : } \\
\text { Condition: }\end{array}$} & \multicolumn{2}{|c|}{ R.C., M, 51 yrs } & \multicolumn{4}{|c|}{ E.N., M, 52 yrs } \\
\hline & Control & $\mathrm{K}$ gluconate & Control & Glucose & Control & $\mathrm{K}$ gluconate \\
\hline \multicolumn{6}{|l|}{ Blood: } & $60 \mathrm{mEq}, \mathrm{iv}$ \\
\hline \multicolumn{7}{|l|}{$\mathrm{NH}_{4}-\mathrm{N}, \mu g / 100 m l$} \\
\hline $\begin{array}{l}\text { Artery } \\
\text { Renal vein } \\
\text { Antecubital vein } \\
\text { Hepatic vein } \\
\text { Jugular bulb } \\
\text { Artery, final }\end{array}$ & $\begin{array}{r}62 \\
123 \\
53 \\
67 \\
57 \\
72\end{array}$ & $\begin{array}{l}59 \\
85 \\
54 \\
61 \\
49 \\
58\end{array}$ & $\begin{array}{r}73 \\
108 \\
76 \\
59 \\
82 \\
76\end{array}$ & $\begin{array}{r}84 \\
126 \\
84 \\
74 \\
74 \\
82\end{array}$ & $\begin{array}{r}112 \\
149 \\
92 \\
74 \\
\\
112\end{array}$ & $\begin{array}{r}89 \\
108 \\
76 \\
59 \\
77\end{array}$ \\
\hline \multicolumn{7}{|l|}{$\mathrm{K}, m E q / L$} \\
\hline $\begin{array}{l}\text { Artery } \\
\text { Renal vein }\end{array}$ & $\begin{array}{l}3.4 \\
3.5\end{array}$ & $\begin{array}{l}4.1 \\
4.3\end{array}$ & $\begin{array}{l}4.4 \\
4.5\end{array}$ & $\begin{array}{l}4.5 \\
4.2\end{array}$ & $\begin{array}{l}3.4 \\
3.5\end{array}$ & $\begin{array}{l}4.2 \\
4.5\end{array}$ \\
\hline \multicolumn{7}{|l|}{$\mathrm{pH}$} \\
\hline $\begin{array}{l}\text { Artery } \\
\text { Renal vein }\end{array}$ & $\begin{array}{l}7.49 \\
7.45\end{array}$ & $\begin{array}{l}7.41 \\
7.39\end{array}$ & $\begin{array}{l}7.43 \\
7.41\end{array}$ & 7.44 & $\begin{array}{l}7.52 \\
7.46\end{array}$ & $\begin{array}{l}7.49 \\
7.49\end{array}$ \\
\hline \multicolumn{7}{|l|}{ Urine: } \\
\hline $\begin{array}{l}\text { Collection time, min } \\
\text { Flow, ml/min } \\
\mathrm{NH}_{4}, \mu E q / \text { min } \\
\mathrm{K}, \mu E q / \min \\
\mathrm{pH}\end{array}$ & $\begin{array}{c}68 \\
1.1 \\
138 \\
35 \\
5.88\end{array}$ & $\begin{array}{l}75 \\
0.9 \\
94 \\
56 \\
5.41\end{array}$ & $\begin{array}{l}70 \\
0.3 \\
13 \\
34 \\
5.67\end{array}$ & $\begin{array}{l}55 \\
0.4 \\
13 \\
27 \\
5.81\end{array}$ & $\begin{array}{l}80 \\
2.1 \\
55 \\
15 \\
6.25\end{array}$ & $\begin{array}{l}70 \\
2.0 \\
34 \\
57 \\
5.57\end{array}$ \\
\hline
\end{tabular}

* These patients were studied during diuretic regimes similar to those employed for the other patients, and they demonstrated comparable blood and urine electrolyte changes. The blood samples for analyses were obtained before and shortly after the infusions. Collections of urine were made for the period just preceding and the period during the infusions of potassium gluconate and glucose. The data pertaining to patient R.C. were obtained on day 2 after the induction of mercurial diuresis. The study involving the glucose infusion in patient E.N. was done the day before the mercurial diuretic was given; the $\mathrm{K}$ gluconate study was done on day 2 after the diuresis. 
supplemental potassium was given than during the control experiment. The pattern of urinary ammonium excretion in the postdiuretic period ( $\mathrm{Ta}$ ble III, experiment 1) was comparable to that noted in the other patients. The administration of potassium orally (Table III, experiment 2 ) resulted in more prompt decreases in urinary ammonium excretion to below control values. Unfortunately, urine $\mathrm{pH}$ determinations were not done.

Venous catheterization studies. Four patients were studied by venous catheterization techniques (Tables IV and V). Renal venous blood ammonium levels during the initial catheterizations were about $50 \%$ higher than arterial levels. Whether or not the administration of calcium chloride influenced the renal venous blood ammonium levels obtained for these patients cannot be determined from the data presented. The differences noted, however, between peripheral artery and renal vein are comparable to those reported by other investigators for normal individuals and for patients with liver disease who were not subjected to acid loading (27-29). In addition, as noted above, the administration of calcium chloride orally had no measurable effect upon arterial blood ammonium concentrations. In these patients, the mercurial diuretic also caused large diureses, losses of electrolytes, hypokalemia, and elevations of arterial blood ammonium levels. The renal venous ammonium levels increased after the diuresis by greater increments than arterial levels. The most striking changes were evident in patient W.D. (Table IV), who, after the diuresis, demonstrated a $50 \%$ decrease in serum potassium concentration, a twofold increase in arterial blood ammonium level, and a fourfold increase in renal venous ammonium level. When $60 \mathrm{mEq}$ of potassium gluconate was given intravenously to W.D. during a 30-minute period, decreases in renal venous and arterial blood ammonium levels occurred in the absence of any change in arterial blood $\mathrm{pH}$.

The immediate effects of potassium gluconate infusions were studied in two additional patients (Table V). The study of patient R.C. was done on day 2 after the induction of a diuresis by the mercurial agent. The administration of potassium gluconate, $30 \mathrm{mEq}$ intravenously in about an hour, was followed by a decrease in the am- monium content of renal venous blood and an increase in blood potassium concentration. The $\mathrm{pH}$ of arterial and of renal venous blood decreased. A similar study done with patient E.N., involving the administration of $60 \mathrm{mEq}$ potassium gluconate in about an hour, yielded a similar result. Decreases in arterial and antecubital venous ammonium levels were also apparent. There were no significant changes in $\mathrm{pH}$ of arterial or of renal venous blood. During the studies of these two patients, urine was collected for the periods preceding and accompanying the infusions of potassium gluconate. In both patients during the infusion of potassium, excretion of ammonium decreased, urine $\mathrm{pH}$ decreased, and excretion of potassium increased.

When technically possible, antecubital and hepatic venous and jugular bulb blood samples were also obtained during the catheterization procedures. In no instance did ammonium levels in blood samples obtained from these sites significantly exceed arterial levels during the initial catheterization studies or those done while the patients were potassium deficient. Extremities, liver, and brain were, therefore, not contributing ammonium to the arterial circulation before or during the potassium-deficiency state. The influence of potassium deficiency on the metabolism of ammonium by gut could not be evaluated by the experimental techniques employed; at least the ammonium levels in hepatic venous blood provided no evidence for increased shunting of ammonium through the liver from the portal system.

An additional control study was done with patient E.N. (Table V). On the day before the administration of the diuretic agent, this patient was given 60 mmoles of glucose intravenously in about an hour. Although adequate rates of urine flow were not obtained, this study demonstrates that the administration of glucose under technical and mechanical conditions simulating those in the later experiment involving potassium administration did not produce significant alterations in the blood or urine constituents measured. The $\mathrm{pH}$ of the urine increased slightly during the glucose infusion. Although the glucose infusion was given in metabolic circumstances that differed from those at the time potassium gluconate was given, the data obtained demonstrate that the changes attributed to potassium gluconate administration 
were not due to an effect of the catheterization procedure itself.

\section{DISCUSSION}

The metabolic responses of patients with cirrhosis of the liver and ascites to acidosis resulting from oral administration of calcium chloride and acute potassium deficiency induced by a mercurial diuresis were evaluated. The results bear on the role of the kidney as a source of blood ammonium in patients with cirrhosis of the liver and on changes in renal ammonium metabolism that occur in potassium-deficient patients. The data are interpreted from these points of view.

Ammonium excretion by the kidney was increased in conjunction with the acidosis resulting from calcium chloride. This increase was unaccompanied by change in arterial blood ammonium level. The increasing urinary ammonium excretion apparently did not take place at the expense of. nor result in, detectable elevation of arterial blood ammonium levels. As pointed out in previous publications. the induction of metabolic acidosis per se does not result in ammonium overloading syndromes in patients with liver disease $(6,30)$.

The administration of the mercurial diuretic, with or without aminophylline, following acid loading with calcium chloride consistently caused a significant diuresis that in some instances was massive. The urinary excretions of potassium associated with the diureses entailed significant losses of intracellular potassium, since their magnitudes were larger than could possibly have originated from extracellular fluid. A relation between serum potassium and arterial blood ammonium levels was evident in the recovery period following the diuretic regimen; decreased potassium levels were related to elevated ammonium concentrations. In the immediate postdiuretic period, decreases in serum potassium levels were usually evident before increases in arterial blood ammonium concentrations occurred: on the other hand, increases in serum potassium preceded decreases in blood ammonium concentrations during recovery. These changes in arterial blood ammonium levels occurred in the absence of any alteration in exogenous nitrogen load, indicating that the increased quantities of ammonium found in the circulation were originating from an internal source.
The above conclusion was further supported by the study of patient E.H. (Table III). In this study, on two consecutive occasions, blood ammonium concentrations increased as hypokalemia developed following the diuretic regimen. The oral administration of potassium gluconate during the second occasion increased the rate at which arterial blood ammonium levels returned toward control and at which urinary ammonium excretion decreased after the diuresis. This effect of potassium in simultaneously decreasing blood and urine ammonium levels suggested that metabolism of ammonium by the kidney was altered with potassium deficiency. Accordingly, the kidney was considered a possible source of the increased circulating ammonium. This hypothesis was supported by the results of the catheterization experiments. In the potassium-deficient patients, renal venous blood ammonium content was increased as compared to values obtained during or after the development of the acidosis. The magnitude of these increases was consistently greater than that noted in arterial or antecubital venous blood. Determination of ammonium concentrations in antecubital and hepatic venous and jugular bulb blood demonstrated that extremities, liver, and brain were not contributing ammonium to the arterial circulation. The decreases in renal venous and arterial blood ammonium levels that resulted from administration of potassium salts orally further demonstrated that the changes were related to potassium deficiency. The decreases in renal venous and arterial blood ammonium levels resulting from potassium administration were not attributable to a diversion of ammonium from blood to urine, since urinary ammonium excretions were not increased. Thus, the mechanisms involved here are apparently different from those that occur after the administration of acetazolamide. This agent produces a bicarbonate diuresis. prompt increase in urine $\mathrm{pH}$, and diversion of ammonium from urine into renal venous outflow (29).

The effects of potassium gluconate infusions on renal ammonium metabolism deserve further comment. Ammonium excretion into the urine is related to the $\mathrm{pH}$ gradient between tubular cell and urine; as $\mathrm{pH}$ decreases, ammonium content increases (31). This relation did not apply in the two patients studied (Table V). With adminis- 
tration of potassium gluconate, urine $\mathrm{pH}$ decreased, but the excretion of ammonium also decreased. Similar changes in urinary excretion of ammonium independent of changes in urine $\mathrm{pH}$ occur during repletion of patients with chronic potassium deficits resulting from chronic diarrhea (32). The decrease in ammonium excretion might result from one of several possible mechanisms. Diversion of ammonium from urine to renal venous outflow may occur; the concomitant decreases in renal venous blood ammonium content eliminate this possibility. Although measurements of renal blood flow were not made, the possibility that alterations in this parameter might account for the observed changes seems remote. Considering the magnitude of observed decreases in the rate of urinary ammonium excretion, we estimated that renal blood flow would have had to increase at least two to three times to account for the decreases in renal venous blood ammonium content, assuming constant rates of production and availability. Occurrence of a decrease in renal blood flow would not negate the interpretation of the data presented here. Alterations in the competition of hydrogen and potassium for tubular secretion that might result from potassium administration seem unlikely because the urine did not become alkaline. Whether or not our patients suffered impairment of some tubular functions related to the potassium deficiency cannot be stated. The concomitant decreases in urinary ammonium excretion and renal venous blood ammonium concentrations resulting from potassium administration suggest that potassium influences renal ammonium metabolism by altering production of ammonia by the tubular cells, or by affecting the diffusion or transport of ammonia (or ammonium) from the cells to tubular urine independent of $\mathrm{pH}$ gradients.

These results obtained in our study provide evidence that renal production of ammonia or availability of this ion is increased in potassiumdeficient patients, although the exact source and the role of potassium in its regulation cannot be stated. The finding of increased glutaminase activity in kidney tissue obtained from potassiumdeficient animals $(33,34)$ suggests that similar increases in glutaminase (or other enzymes) activity resulting in increased ammonia production may be operative in this circumstance in man. It is also possible that renal ammonia production is unaltered by potassium deficiency, but that availability of ammonia produced in tubular cells is affected by the presence or absence of potassium, which influences permeability of tubular cell membranes. If the latter hypothesis applied, the observed increases in glutaminase activity might represent compensation for the tendency of intracellular ammonia concentration to decrease due to increased passage of ammonia from the cells. A relative increase in urinary ammonium excretion in relation to urine $\mathrm{pH}$ has been demonstrated in potassium-deficient human subjects (26, $32,35)$. The data presented here demonstrate that this increase in anmonium excretion is attributable to increased renal ammonia production or to increased availability of ammonia from tubular cells.

The applied significance of our findings can be summarized briefly as follows. Renal ammonium metabolism is altered in patients rendered acutely deficient of potassium. As a result of increased renal ammonia production or availability of ammonia in renal cells, the diffusion of ammonia into urine and renal venous blood is increased. This accounts for the increased urinary ammonium excretion at a given urine $\mathrm{pH}$ that occurs in potassium-deficient patients. In patients with normal hepatic function, the ammonium that diffuses into the renal vein is promptly synthesized into urea. The urea originating from this source may contribute to increases in blood urea nitrogen concentration that occur in some patients who are potassium depleted, especially if renal disease coexists or if dehydration limits glomerular filtration. In patients with hepatic disease the ammonium reaching the systemic circulation from the renal vein is not removed adequately by way of urea synthesis. This is reflected in increased arterial blood ammonium levels that occur in relation to hypokalemia. This internal ammonium load may precipitate the syndrome of impending hepatic coma in susceptible patients. In these instances reversibility of the biochemical and clinical phenomena described depends upon the administration of potassium, which operates in some unknown fashion to decrease availability of ammonium from the kidney.

Most of the data reported here concern patients with hepatic disease and normal kidney function 
who were rendered acutely deficient of potassium by a mercurial diuretic regimen. It seems probable, however. that similar mechanisms may operate in patients rendered potassium deficient by other diuretic agents, by dietary potassium restriction, or as a result of extrarenal losses of potassium secondary to chronic vomiting or diarrhea.

\section{SCMMARY}

The relation of acute potassium depletion resulting from a mercurial diuretic regimen to renal ammonium metabolism was evaluated in patients with cirrhosis of the liver and ascites.

The mercurial diuretic caused significant potassium deficits. Decreases in serum potassium concentration occurred that were followed by and reciprocally related to increases in arterial blood ammonium concentrations. Correction of potassium deficits by diet or by oral potassium supplements was followed by return of blood ammonium levels to control values.

The kidney was investigated as the possible source of the increased concentrations of circulating ammonium found in the potassium-deficient patients. Arterial, and peripheral and renal venous blood samples were obtained by catheterization techniques before and after induction of potassium deficiency. The greatest increases in ammonium concentration occurred in renal venous blood. Extremities. liver, and brain did not contribute ammonium to the circulation. With the intravenous administration of potassium gluconate to deficient subjects, renal venous blood ammonium concentrations and urinary ammonium excretions promptly decreased; ammonium was not diverted from renal venous outflow to urine.

In susceptible patients with liver disease who are rendered potassium deficient, ammonium delivered to the systemic circulation from kidney may precipitate the impending hepatic coma syndrome.

Our findings demonstrate that renal production of ammonium or its availability to tubular fluid and to renal venous outflow is increased in potassium-deficient patients. This influence of potassium in the regulation of ammonium metabolism by the kidney may explain the alterations in ammonium and urea nitrogen metabolism that occur in some potassium-deficient subjects with or without hepatic disease.

\section{REFERENCES}

1. Read, A. E., J. Laidlaw, R. M. Haslam, and S. Sherlock. Neuropsychiatric complications following chlorothiazide therapy in patients with hepatic cirrhosis: possible relation to hypokalæmia. Clin. Sci. 1959, 18, 409.

2. Posner, J. B., and F. Plum. The toxic effects of carbon dioxide and acetazolamide in hepatic encephalopathy. J. clin. Invest. 1960, 39, 1246.

3. Webster, L. T., Jr., and C. S. Davidson. Production of impending hepatic coma by a carbonic anhydrase inhibitor, Diamox. Proc. Soc. exp. Biol. (N. Y.) 1956, 91, 27.

4. Baertl, J. M., S. M. Sancetta, and G. J. Gabuzda. Relation of acute potassium depletion to renal ammonium production in patients with cirrhosis (abstract). Gastroenterology 1960, 38, 803.

5. Mackie, J. E., J. M. Stormont, R. M. Hollister, and C. S. Davidson. Production of impending hepatic coma by chlorothiazide and its prevention by antibiotics. New Eng. J. Med. 1958, 259, 1151.

6. Schwartz, R., G. B. Phillips, G. J. Gabuzda, Jr., and C. S. Davidson. Blood ammonia and electrolytes in hepatic coma. J. Lab. clin. Med. 1953, 42, 499.

7. Artman, E. L., and R. A. Wise. Hypokalemia in liver cell failure. Amer. J. Med. 1953, 15, 459.

8. Amatuzio, D. S., F. Stutzman, N. Shrifter, and S. Nesbitt. A study of serum electrolytes ( $\mathrm{Na}, \mathrm{K}$, $\mathrm{Ca}, \mathrm{P}$ ) in patients with severely decompensated portal cirrhosis of the liver. J. Lab. clin. Med. 1952, 39, 26.

9. Sherlock, S. Pathogenesis and management of hepatic coma. Amer. J. Med. 1958, 24, 805.

10. Gabuzda, G. J. Hepatic coma: clinical considerations, pathogenesis, and management in Advances in Internal Medicine, W. Dock and I. Snapper, Eds. Chicago, The Year Book Publishers, 1962, vol. 11, p. 11.

11. Bowes, A. D., and C. F. Church. Food Values of Portions Commonly Used, 8th ed. Philadelphia, Anna DePlanter Bowes, 1956, p. 110.

12. Mattice, M. Bridges' Food and Beverage Analyses, 3rd ed. Philadelphia, Lea \& Febiger, 1950, p. 412.

13. Watt, B., and A. Merrill. Composition of Foods, Agriculture Handbook No. 8. Washington, D. C., U. S. Department of Agriculture, 1950.

14. Davidson, C. S., L. E. Clifcorn, P. A. Clifford, G. J. Gabuzda, and C. Robinson. Sodium Restricted Diets: The Rationale, Complications and Practical Aspects of Their Use. Washington, D. C., National Research Council, Publication 325, 1954.

15. Bills, C. E., F. G. McDonald, W. Niedermeier, and M. C. Schwartz. Sodium and potassium in foods and waters. Determination by the flame photometer. J. Amer. diet. Ass. 1949, 25, 304.

16. Keys, A. A rapid micro-Kjeldahl method. J. biol. Chem. 1940, 132, 181. 
17. Owings, R. H., and E. E. Mandel. Studies in nonprotein nitrogen. I. A convenient method for measuring urea in blood. Proc. Soc. exp. Biol. (N. Y.) 1951, 78, 363.

18. Hald, P. M. Determinations with flame photometer in Methods in Medical Research, M. B. Visscher, Ed. Chicago, The Year Book Publishers, 1951, vol. 4, p. 79.

19. Van Slyke, D. D., and A. Hiller. Application of Sendroy's iodometric chloride titration to proteincontaining fluids. J. biol. Chem. 1947, 167, 107.

20. Cotlove, E., H. V. Trantham, and R. L. Bowman. An instrument and method for automatic, rapid, accurate, and sensitive titration of chloride in biologic samples. J. Lab. clin. Med. 1958, 51, 461.

21. Conway, E. J. Microdiffusion analysis and volumetric error, 3rd ed. London, D. Van Nostrand 1950.

22. McDermott, W. V., Jr., and R. D. Adams. Episodic stupor associated with an Eck fistula in the human with particular reference to the metabolism of ammonia. J. clin. Invest. 1954, 33, 1.

23. Webster, L. T., Jr., C. S. Davidson, and G. J. Gabuzda. Effect on portal blood ammonium of administering nitrogenous substances to patients with chronic hepatic disease. J. Lab. clin. Med. 1958, 52, 501.

24. Sartorius, O. W., J. C. Roemmelt, and R. F. Pitts. The renal regulation of acid-base balance in man. IV. The nature of the renal compensations in ammonium chloride acidosis. J. clin. Invest. 1949, 28, 423.

25. Schwartz, W. B., R. L. Jenson, and A. S. Relman. The disposition of acid administered to sodiumdepleted subjects: the renal response and the role of the whole body buffers. J. clin. Invest. 1954, 33,587 .
26. Clarke, E., B. M., Evans, I. MacIntyre, and M. D. Milne. Acidosis in experimental eletrolyte depletion. Clin. Sci. 1955, 14, 421.

27. White, L. P., E. A. Phear, W. H. J. Summerskill, and S. Sherlock. Ammonium tolerance in liver disease: observations based on catheterization of the hepatic veins. J. clin. Invest. 1955, 34, 158.

28. McDermott, W. V., Jr., R. D. Adams, and A. G. Riddell. Ammonia metabolism in man. Ann. Surg. 1954, 140, 539.

29. Owen, E. E., M. P. Tyor, J. F. Flanagan, and J. N. Berry. The kidney as a source of blood ammonia in patients with liver disease: the effect of acetazolamide. J. clin. Invest. 1960, 39, 288.

30. Gabuzda, G. J., Jr., G. B. Phillips, and C. S. Davidson. Reversible toxic manifestations in patients with cirrhosis of the liver given cation-exchange resins. New Eng. J. Med. 1952, 246, 124.

31. Pitts, R. F. Renal excretion of acid. Fed. Proc. 1948, 7, 418.

32. Schwartz, W. B., and A. S. Relman. Metabolic and renal studies in chronic potassium depletion resulting from overuse of laxatives. J. clin. Invest. 1953, 32, 258.

33. Iacobellis, M., E. Muntwyler, and G. E. Griffin. Kidney glutaminase and carbonic anhydrase activity and tissue electrolyte composition in potassium-deficient dogs. Amer. J. Physiol. 1955, 183, 395.

34. Muntwyler, E., M. Iacobellis, and G. E. Griffin. Kidney glutaminase and carbonic anhydrase activities and renal electrolyte excretion in rats. Amer. J. Physiol. 1956, 184, 83.

35. Huth, E. J., R. D. Squires, and J. R. Elkinton. Experimental potassium depletion in normal human subjects. II. Renal and hormonal factors in the development of extracellular alkalosis during depletion. J. clin. Invest. 1959, 38, 1149. 